This accepted manuscript is licensed under a Creative Commons Attribution-NonCommercial-NoDerivatives 4.0 International License.

\title{
City-regionalism as countervailing geopolitical processes: The evolution and dynamics of Yangtze River Delta region, China
}

$\mathrm{Yi} \mathrm{Li}^{\mathrm{a}}$ and Andrew E.G. Jonas ${ }^{\mathrm{b}}$

aSchool of Public Administration, National Research Centre for Resettlement, Hohai University, Nanjing 210098, China, yili@hhu.edu.cn, 86-25-86223372

bDepartment of Geography, Geology and Environment, University of Hull, HU6 7RX, United Kingdom, A.E.Jonas@hull.ac.uk, +44 (0) 1482465368

This is the Accepted Manuscript version of an article published online in Volume 73 in progress (August 2019) in Political Geography and available at: https://doi.org/10.1016/j.polgeo.2019.05.014

\begin{abstract}
In many countries, national governments deploy city-regionalism not simply as a domestic policy tool but also as a geopolitical device enabling the internationalization of state territory and economy. Focusing upon the evolution of Yangtze River Delta (YRD) region in China, this paper offers new insights into the close associations between Chinese city-regionalism and the geopolitical orchestration of national development. Rather than conceived as an inevitable outcome of contemporary globalization processes, the development of YRD region is instead examined against the changing geopolitical dynamics and national objectives of the Chinese Communist Party (CCP) from 1949 to the present day. In the early phase of CCP rule, the
\end{abstract}


This accepted manuscript is licensed under a Creative Commons Attribution-NonCommercial-NoDerivatives 4.0 International License.

development of regional urban centres, such as Shanghai in YRD region, was an instrument of national territorial integration and class unity. Following economic reforms in the 1980s, the formal designation of YRD as a city-region reflected the Chinese state's aspiration for accelerated economic growth and the internationalization of the domestic economy. Now confronted with widening regional inequalities, the Chinese state has greatly expanded YRD region to incorporate peripheral cities and provinces for the sake of regionally coordinated development. Even as YRD transforms into a global city-region, Shanghai seemingly separates itself functionally and discursively from the rest of the region. In departing from contemporary post-Westphalian or hyper-globalist perspectives on the rise of global city-regions in a seemingly stateless world, the paper provides a new interpretation of Chinese city-regionalism as a case of countervailing geopolitical processes at work within and beyond national state borders.

Keywords: city-regionalism, state internationalization, geopolitics, governance, China

\section{INTRODUCTION}

Today, the emergence of mega-urban regions performing an increasingly prominent role in global processes of production, accumulation, and territorial redistribution has captivated the imaginations of academics and political leaders alike (Florida, 2008; Hall, 2009; Harrison \& Hoyler, 2015; Scott, 2001). For some, the rise of so-called 'global city-regions' (Scott, Agnew, Soja, \& Storper, 2001) seemingly portends the demise of the Westphalian geopolitical order that was based around sovereign territorial nation-states and its eventual replacement by a hyperglobalizing world of city-based networks and political interactions (Taylor, 2011, 2013; but see Dierwechter, 2018). For others, such a development represents not so much a threat to the regulatory authority and sovereignty of the nation-state as a deepening of processes of 
This accepted manuscript is licensed under a Creative Commons Attribution-NonCommercial-NoDerivatives 4.0 International License.

neoliberalism and corresponding strategic efforts on the part of the national state to establish new competitive forms of territorial administration at the city-regional scale (Brenner, 2004;

Wachsmuth, 2015; Wu, 2016). At issue is the relationship between globalization, the emergence of new city-regional territorial structures, and the geopolitical integrity of the nation-state.

The rise of city-regionalism not only poses a variety of political, administrative and regulatory problems for the nation-state but it also represents a challenging proposition for critical geopolitical thinking about emerging role of different territorial formations in the global economy. Notably, the rise of city-regionalism potentially usurps the existing international political order based upon sovereign nation-states and relatively fixed state territorial borders. Accordingly, it is suggested that global city-regions rather than national states are becoming the chief architects of a global economy structured around globally-interconnected city networks (Scott, 2001; Florida, 2008; Taylor, 2013). By way of contrast, a critical geopolitical perspective seeks to demonstrate how national states incorporate city-regionalist policies, discourses and imaginaries into their international relations toolkit, thereby circumnavigating the intellectual ‘territorial trap’ (Agnew, 1994; 1998) which treats domestic territorial politics and international relations as completely separate spheres of state policymaking (see Ó Thuathail, 1998, 21-22). From this perspective, national states harness city-regionalism as a geopolitical device not simply to manage domestic problems of territorial distribution but also to promote the international competitiveness and territorial integrity of the nation-state (Jonas and Moisio, 2018; Kangas, 2013).

Claims to the effect that the rise of city-regionalism signals the emergence of a stateless world order are further called into question by the experiences of developmental states in the global South, which have used the powerful imaginary of the emergent global city-region to 
This accepted manuscript is licensed under a Creative Commons Attribution-NonCommercial-NoDerivatives 4.0 International License.

achieve national development goals (Roy, 2009). The selective promotion of global city-regions by the development state often symbolizes national progress and identity, prompting scholars to pay close attention to how domestic territory and international geopolitics are becoming fused together in national imaginaries (Bunnell, 2002). Likewise, nation-states in the global North increasingly deploy city-regionalism as a policy tool for addressing a variety of domestic political problems - especially vexed issues of political citizenship and identity (Calzada, 2018) - whilst at the same time advancing the state’s wider geopolitical interests (Harrison, 2008; Jonas \& Moisio, 2018). If, as Storper (2013) has argued, national politics could be rendered much more visible in urban and regional analysis, so too the analysis of city-regionalism could help to shed further light on the wider geopolitical role of the national state (Jonas, 2013; and see Scott, 2019).

In his essay on the 'geopolitics of capitalism' written towards the end of the Cold War era, Harvey (1985) argued that efforts on the part of capital and its national political allies to export crises of devaluation constantly threatened to undermine the territorial coherence of domestic regional class alliances and international geopolitical alignments. The rise to dominance of mega-urban regions in today's landscape of global accumulation means that capitalism potentially contains the seeds of all sorts of new city-regional political tensions and alliances along with the possibility of new geopolitical alignments. Accordingly, efforts to examine city-regionalism as an integral aspect of the 'geopolitics of capitalism' have addressed two further processes, firstly, the interests and agendas of different national political actors and, secondly, the territorial politics of collective provision and social distribution (Jonas, 2013). In light of this, China - a country with a well-documented record of national development policies aimed promoting urban and regional growth and redistribution (see Huang, 2006; Wu, 2016) - 
This accepted manuscript is licensed under a Creative Commons Attribution-NonCommercial-NoDerivatives 4.0 International License.

provides a compelling case for investigating geopolitical processes operating around its major city-regions as the Chinese state strives to reconcile domestic problems of regional inequality with its internationalization agenda. In China, the territorial pattern of human settlement notably the development of a nationally coherent and cohesive network of functional city-regions - is manifestly a contingent territorial outcome of dynamic global and domestic relations and a state-orchestrated territorial politics of distribution.

The critical geopolitical perspective adopted in this paper represents a significant departure from recent studies of city-regional agglomerations in China. Such studies have hitherto prioritized knowledge of relational economic processes, such as foreign direct investment and global production networks, which seemingly operate without regard to national and regional political boundaries (Wei, 2007; Zhao \& Zhang, 2007). ${ }^{1}$ For example, the literature on Global Production Networks (GPNs) emphasizes a strategic coupling of the power of transnational firms and national states in enabling territorially-based accumulation strategies around and within China’s rapidly globalizing city-regions (Wei, 2010). Such city-regions contain numerous territorial-administrative and governance challenges, including the problem of jurisdictional fragmentation and unregulated inter-city competition, which in turn can disrupt the

\footnotetext{
${ }^{1}$ A rich lexicon has emerged to describe these new urban forms, such as 'urban-region clusters,' 'mega-urban agglomerations,' and 'global city-regions’ (Moisio and Jonas, 2018). Although such terms usefully capture certain economic characteristics, in this paper we use terms like 'city-region' and 'city-regionalism' to suggest that the state strives - often with mixed success to ensure that such forms exhibit a certain degree of territorial political coherence in addition to economic functionality.
} 
This accepted manuscript is licensed under a Creative Commons Attribution-NonCommercial-NoDerivatives 4.0 International License.

accumulation strategies of locally-based transnational firms (Yeh \& Xu, 2011). The GPN

literature, however, suggests that local and regional political actors can address such

distributional problems by scaling up to global networks and harnessing supranational

governance capacities, thereby separating the governance processes operating within global city-

regions from the (Chinese) state’s internationalization agenda (Yang \& Li, 2013).

In a similar vein, scholarly interest in China’s contemporary foreign policy agenda has tended to obfuscate the importance of city-regionalism to the process of state internationalization. For example, Harris $(2014,3)$ provocatively refers to China’s emerging foreign policy as some “contingent” evolutionary response to ad hoc international or domestic events yet offers little analysis of how such geopolitical contingencies have shaped, or are in turn shaped by, the Chinese state's approach to the rapid rise and spread of city-regions across its territory. ${ }^{2}$ As Woon (2018) has recently argued, examining China’s historical ‘contingencies’ from a critical geopolitics perspective helps to shed light on the state's wider engagements in the world. Even when the national state has been a particular focus of city-regional analysis, the emphasis is often on urban policy and planning rather than on how a specifically Chinese approach to city-regionalism has evolved in relation to domestic and international geopolitical processes (Luo \& Shen, 2009). A notable exception is Wu (2016), who divides the recent history

${ }^{2}$ In a similar vein, researchers acknowledge a link between China’s growing geopolitical influence and Chinese investments in energy and infrastructure projects in selective countries of the global South (Mohan and Tan-Mullins, 2018). Yet little is known about the impact of these new geopolitical alignments on levels of foreign direct investment in corresponding projects across Chinese city-regions. 
This accepted manuscript is licensed under a Creative Commons Attribution-NonCommercial-NoDerivatives 4.0 International License.

of Chinese city-regionalism into three periods: state socialism (1949-1978), market reform (1979-2000), and post-reform internationalization (2001 to the present). Whereas Wu places theoretical emphasis upon seeing city-regionalism as an outcome of internal state spatial selectivity, in this paper we not only examine how city-regionalism became a domestic policy objective of the Chinese socialist state during the Cold War era but also expose some of the contingent and countervailing geopolitical processes at work within China’s more recent developmental trajectory. Our argument takes the following form.

China’s regional urbanization processes, and hence the state's particular approach to cityregionalism, has been deeply imprinted in the ruling Chinese Communist Party's (CCP) national political agenda since the creation of the People’s Republic of China in 1949 (Chung, 2015). China’s one-party, unitary political system has emphasized absolute power in the central government and, in particular, the Central Committee of the CCP (Huang, 1996; Lim, 2016). In comparison to western democracies, this fusion of the CCP and the national state (i.e. the partystate) leaves little or no scope for domestic public opinion and electoral processes to shape cityregion governance and administration 'from below'. Therefore, it potentially makes the role of the national state and its geopolitical motives far more transparent and visible in city-regional analysis. When examined as a key dimension of the Chinese state’s contingently evolving foreign policy agenda, the geopolitical motives and discourses underpinning the recently emerging city-regionalism have tended to converge around the CCP's attempts to promote state internationalization, on the one hand, and secure the national political authority of the ruling CCP by managing territorial distribution, on the other.

Drawing upon a case study of Yangtze River Delta (YRD) region, the remainder of the paper provides an overview and interpretation of the variety of contingencies (discursive, 
This accepted manuscript is licensed under a Creative Commons Attribution-NonCommercial-NoDerivatives 4.0 International License.

material, ideological, etc.) influencing how the Chinese state has shaped city-regionalism in the service of national geopolitical imaginaries and objectives from 1949 to the present day. In setting about this task, we do not treat YRD region as ontologically or epistemologically pregiven; for example, we do not regard its present form to be the inevitable outcome of contemporary globalization processes. Rather our interest is in the many different ways in which the material, political and discursive manifestations of YRD as a more or less global city-region help to shed light on the countervailing geopolitical processes operating within the Chinese state.

The first two sections of the paper establish an alternative reading of Chinese cityregionalism, highlighting the role of domestic and international geopolitical processes in the social and political construction of territory during three phases of national state development since 1949. These sections bring together prior research on state spatial restructuring in China and additional evidence from secondary sources dating from 1949 to the present day, including regional policies and plans, sub-national administrative documents, National Five-Year Plans, monographs, newspaper reports and websites. The paper then turns to a case study of YRD region during each phase of Chinese city-regionalism, drawing upon a long-term study of regional governance processes in YRD and follow-up interviews and observational fieldwork conducted in Shanghai and YRD during 2016 and 2017. The observational fieldwork involved a visit to the Shanghai Urban Planning Exhibition Center, in which the latest Shanghai Municipal Plan was on public show, as well as site visits to cities and local jurisdictions outside Shanghai Municipality to investigate emergent regional collaborative initiatives. Alongside the observational fieldwork, we conducted six semi-structured interviews and held informal discussions with urban planners, policy makers and government officers familiar with local and regional development in Shanghai and YRD region. In the conclusion, we argue that the 
This accepted manuscript is licensed under a Creative Commons Attribution-NonCommercial-NoDerivatives 4.0 International License.

emergence of YRD city-region is not a singular and inevitable outcome of the rescaling of the Chinese state. Nor is it simply a case of a new hyper-global world order emerging around a putative network of competitive global city-regions. Instead, it is possible to discern countervailing geopolitical unfolding across YRD region. These processes emerge from efforts by the Chinese national state - notably, the CCP - to balance its internationalization and foreign policy agendas against all sorts of socio-territorial distributional challenges, which have arisen as a result of the rapid growth of the country’s major city-regions including YRD.

\section{CITY-REGIONALISM REVISITED: A GEOPOLITICAL PERSPECTIVE}

The rise of city-regions - and so-called 'global city-regions' in particular - has stimulated much debate and no little polemical analysis on the part of policymakers, social scientists and urban scholars regarding the nature of territorial organization in an era of intensifying economic and political globalization (for recent overviews, see Moisio \& Jonas, 2018; Scott, 2019). Notably, the rise of such city-regions provides further evidence that industries operating in key growth sectors of the global economy (e.g., finance, high technology, etc.) tend to prosper because of the benefits of clustering, agglomeration and related spatial-economic processes typically found within such regions (Porter, 2001; Scott, 1998; Storper, 2013). Given their polycentric form, moreover, global city-regions contain all sorts of political tensions and challenges around planning and social provision, which can pose problems for national and subnational territorial administration (Scott, 2012). Nonetheless, studies by planners and political scientists suggest that local political actors operating in such city-regions have a tremendous capacity to circumnavigate perceived weaknesses in national economic planning and state social provision (Kantor et al., 2012; Neuman \& Hull, 2011). Indeed, so-called 'global city-regions’ are 
This accepted manuscript is licensed under a Creative Commons Attribution-NonCommercial-NoDerivatives 4.0 International License.

often regarded to be more functional and efficient administrative and territorial governance structures than their host nation-states.

Whereas previous work has prioritized the study of economic governance processes operating within global city-regions, scholarly attention is now turning to the role of the national state in the political construction of city-regionalism 'from above' and, conversely, that of business and other non-state organizations 'from below' (Harrison, 2008). Such perspectives have opened up the possibility of exposing the countervailing societal forces and spatial interests shaping different concrete manifestations of city-regionalism. This development, in turn, marks growing interest in investigating the emerging tensions between the city and the nation-state during an era characterized by inter alia an intensification of globalization processes, the resurgence of nationalism, and the emergence of a host of new domestic and international societal tensions. This era seemingly portends the demise of a world system based around sovereign and independent territorial states and its replacement by a system comprised of inter alia resurgent economic regions, inter-connected global cities, mega-urban regions, and quasiautonomous city-states (Ohmae, 1996; Scott, 2001; Taylor, 2013).

However, recent research has started to question whether the Westphalian political order based on territorial nation-states is in terminal demise. In one influential body of literature, the rise of city-regionalism represents the specific outcome of the rescaling of the state, a process that in fact depends upon the activation of the regulatory capacities of the national state itself (Brenner, 2004; Wu, 2016). Driven by a need to correct regulatory deficits associated with neoliberalism, city-regionalism necessitates a simultaneous upscaling of state structures at the transnational scale and a downscaling around competitive forms of city-regional governance what has been dubbed in the North American context as 'competitive multi-city regionalism' 
This accepted manuscript is licensed under a Creative Commons Attribution-NonCommercial-NoDerivatives 4.0 International License.

(Wachsmuth, 2017).

The concept of state rescaling offers a powerful meta-theoretical device for explaining the rise of competitive forms of city-regionalism but has been found wanting when it comes to explaining the full diversity of state formation processes and outcomes in different national contexts (Bristow, 2013; Jonas \& Moisio, 2018; MacLeavy \& Harrison, 2010; Rees \& Lord, 2013). Notably, the state rescaling literature often underestimates the effect of domestic politics and popular-democratic struggles on the allocation and distribution of social functions and powers at different scales of the state (Cox, 2009, 2013; Park, 2008). Even if populist social movements are spatially contained or muted, it is still necessary to examine how and by what measures the state manages the territorial politics of distribution. In the case of Chinese cityregionalism, for example, “the 'politics of redistribution' outside the state sector are not fully developed to drive the formation of city-region governance and the governance of the city-region is still a state-imposed administrative process” (Wu, 2016, 1139).

A further criticism of the state rescaling literature is the tendency to elide otherwise quite disparate political processes of nation building, neoliberalism and competitiveness in the rationalities guiding changes of statehood at the level of city-regions (Harding, 2007; Lord, 2009). Knowledge of the effects of neo-liberalism on domestic territorial competition often comes at the expense of that of the state's wider geopolitical motives. In developing countries of the global South, national governments have sought to connect global economic prosperity and national development to mega-urban regional formations, which in turn deploy imagery and ideas that are replete with national symbolism as well as wider geopolitical aspirations (Roy, 2009). Likewise, small states in the global North frequently deploy city-regionalism as a device to promote territorial competition and thereby internationalize national state territory (Jonas \& 
This accepted manuscript is licensed under a Creative Commons Attribution-NonCommercial-NoDerivatives 4.0 International License.

Moisio, 2018). As such, it is not sufficient to identify whether or how governance is scaling up or down to city-regions. What also matters is the manner in which, given an ever-fluctuating geopolitical landscape of capitalist development, city-regionalism interfaces with wider struggles around the territorial structure of the state as it constantly struggles to reconcile the promotion of urban development, on the one hand, and manage socio-territorial distributional pressures emerging from civil society, on the other (Cox \& Jonas, 1993; Jonas et al., 2014; Scott, 2019). By focusing on how the state differently positions city-regions within national and international development frameworks over time, it might be possible to uncover the countervailing geopolitical forces and tensions shaping how state power coalesces or fragments around cityregions (Harrison, 2008, 2010) and how, in turn, city-regional political actors, investments and territories are geopolitically (re)aligned (Jonas, 2013).

In summary, urban scholars now acknowledge that a range of geopolitical tensions and processes are involved in producing a variety of city-regionalisms across very different national state territorial formations (Calzada, 2018; Harrison, 2012; Jones and MacLeod, 2004; Kangas, 2013; Storper, 2013). Instead of threatened by the rise of global city-regions, the national state itself often geopolitically orchestrates city-regionalism to achieve domestic and international policy objectives (Jonas, 2013). At the same time, these potentially divergent domestic and international agendas can give rise to countervailing geopolitical processes within city-regions, depending on how various political actors and material interests stand to gain or lose from emergent city-regional alliances and geopolitical alignments. The paper now examines the countervailing geopolitical processes contributing to dynamic and ever-evolving city-regional imaginaries, discourses and material outcomes in socialist China since 1949 as a prelude to a detailed case study of city-regionalism in YRD region. 
This accepted manuscript is licensed under a Creative Commons Attribution-NonCommercial-NoDerivatives 4.0 International License.

\section{EVOLVING CITY-REGIONALISM IN CHINA AND ITS VARIETY OF}

\section{GEOPOLITICAL RATIONALITIES}

In China, the received view is that the city-region became a prominent scale of subnational governance in the early 2000s (Li \& Wu, 2012). National policy debate about cityregionalism in fact has a much longer pedigree, gathering momentum in the 1980s and early 1990s when China’s rapid economic development ushered in powerful forces of urban agglomeration and massive urban land expansion in certain areas (Xu \& Li, 1990). Notably, the global city-region developments identified as the Bohai Sea Rim ((Bei)Jing-(Tian)Jin-Ji(Hebei), or JJJ for short), Pearl River Delta (PRD) and YRD stand out, these being regions defined by peri-urbanization, contiguous built urban development, concentration of urban population and active global economic integration (Hall, 1999; McGee, 1991). According to China’s National Bureau of Statistics, YRD region alone accounts for $12 \%$ of the national population, 36\% of national exports, and 47\% of utilized foreign capital (Table 1).

\section{+++Insert Table 1 'Key territorial, economic and demographic indicators of YRD in 2015' about here+++}

Notwithstanding the recent and prolific rise of these regional urban formations, political intervention by the national state at the city-regional scale is in fact hardly new in China. Viewed over a longer time period, there has been a gradual yet relentless convergence of domestic policy around city-regions, which can be dated back to the socialist period over seventy years ago; in other words, city-regionalism emerged de facto as a domestic policy tool well before the rise of today’s mega-city regions. 
This accepted manuscript is licensed under a Creative Commons Attribution-NonCommercial-NoDerivatives 4.0 International License.

During the state socialism era (1949-1978), there was initially little recognition of cityregions per se in domestic policy; nevertheless, territorial policy in China was often orchestrated at the regional level around a two-fold development strategy that had significant implications for the spatial pattern of national settlement in China. On the one hand, the socialist state prioritized the integration of a unitary state and the consolidation of CCP leadership through crossprovincial regional organizations (Li \& Wu, 2012; Lim, 2016). Under the leadership of Chairman Mao Tse-tung, China’s domestic approach to territorial development reflected a concern for national security in the context of the Cold War with the USA plus ongoing threats from Chinese Nationalists in Taiwan, the Sino-Indian border war, and the deteriorating relations with the Soviet Union in the early 1960s. The principle of national political integration thus had a great impact upon external and internal economic policy formulation. The ideology and discourse of ‘economic cooperation’ (jingji xiezuo) and ‘regional self-sufficiency’ (ziji zizu) was sustained in the context of rising hostile international environment and geopolitical considerations.

On the other hand, the communist party-state was desperate to demonstrate its legitimacy and superiority over rival regional factions and geopolitical alliances through achieving rapid industrialization and balanced development (Huang, 2006). The top-down allocation of resources within a socialist planned economy enable the newly formed Chinese socialist state to orchestrate national industrialization to catch up with the West especially the UK and USA (Wu, 2010). It also restricted autonomous regional trade and channeled state investment towards inland cities and regions in line with socialist ideologies of equality and working class unity, resulting in the development of major new industrial centres especially in parts of central China (Cannon, 1990). Meanwhile, urbanization was strictly controlled in order to reduce expenditures 
This accepted manuscript is licensed under a Creative Commons Attribution-NonCommercial-NoDerivatives 4.0 International License.

on collective social provision and invest the savings in industrial development (Chan, 1992).

Millions of urban youth were deported to the countryside after the failure of Great Leap Forward (1958-1960) and during the decade of Cultural Revolution (1966-1976) as China found it increasingly difficult to support collective provision for its urban population (Kirkby, 1985). In short, during the early phase of socialism in China state interventions around urbanization and regional policy became in effect contingent geopolitical instruments by which the Chinese national state could reassert its authority, consolidate national economic control, and rebuild national political unity around socialist principles and ideology.

Despite promoting its economic development model of nationalized production and accumulation, the socialist state's dream of rapid industrialization ultimately failed. During the ensuing decades (1979-2000), equilibrium development on the premise of self-sufficiency eventually gave way to market reforms and increasing internationalization. During this second phase of city-regionalism, urban and regional specialization based on comparative advantages was encouraged in order to boost overall economic productivity and efficiency (Wu, 2010). In practice, the state selected certain city-regions - especially those along the eastern coastal corridor - as spaces of policy experimentation open to marketization and global circuits of capital. The state's approach to territorial organization was guided under new domestic policy discourse such as ‘regional cooperation’ (quyu hezuo) and ‘economic region’ (jingji qu). This was in sharp contrast to the rigid command of 'economic cooperation' in the earlier state socialism era. National economic policy likewise refocused around a domestic policy discourse that favoured selective urban development in coastal regions alongside a growing recognition of the need to internationalize the economy in order to stimulate domestic markets and encourage economic regionalization ( $\mathrm{Li} \& \mathrm{Wu}, 2018)$. Whereas in the socialist period the economic 
This accepted manuscript is licensed under a Creative Commons Attribution-NonCommercial-NoDerivatives 4.0 International License.

contribution and administrative significance of the city within regional development processes was significantly undermined, under market reforms in the 1980s and 1990s regional economic activities were concentrated around the central city and its surrounding hinterland. In other words, cities were now designated by the state as regional growth poles, thereby blurring the administrative territorial distinction drawn between 'city,' 'region' and 'countryside' in domestic economic policy. Certain city-regions in select areas - notably, the fastest-growing east coast regions - were now at the forefront of national efforts to liberalize the economy and integrate with the global system of capitalism.

The third and latest phase of city-regionalism in China begins with a deepening of global economic integration initiated after China’s entry to the World Trade Organization (WTO) in 2001. Based on the economic regions created in the 1990s, the national state undertook further efforts to consolidate a limited number of major regional conurbations into its vision of global city-regions to promote international competition. This included YRD, PRD, JJJ as well as some other inland metropolitan areas and even cities in remote border regions (for example, Yunnan province, as documented in $\mathrm{Su}, 2014)$. Along with the intensity and polarization of urbanization processes underway, stresses nonetheless were readily apparent not only in the realm of urban planning and governance (Xu \& Yeh, 2008) but also in state-society relations, environmental sustainability and a host of issues related to overall spatial distribution of economic growth (He \& Lin, 2015).

The uneven geographies of economic growth and urbanization soon reconfigured the political dynamics between east and west regions, between urban and rural areas, and hence also between global city-regions and ‘ordinary cities’ (Robinson, 2006). The enlarging city-regional disparities also began to pose potential challenges to the territorial political integration and social 
This accepted manuscript is licensed under a Creative Commons Attribution-NonCommercial-NoDerivatives 4.0 International License.

stability of the Chinese state, potentially undermining its geopolitical status in the wider world (Wang \& Hu, 1994). In the light of sustaining party survival, the state responded by ushering in an array of regional planning and territorial policy measures under the political discourse of regionally coordinated development (Chung, 2015; Fan, 2006). Consequently, city-regional coordination quickly came to dominate government regional policies. When compared with the earlier discourses of ‘economic cooperation’ and 'regional cooperation’, ‘city-regional coordination' (quyu xietiao) is potentially far more comprehensive and territorially explicit in nature. The idea of ‘city-regional coordination’ translates into not only economic/market integration and balanced regional development but also a regional approach to urban and regional development (Wu, 2016) along with 'overall planning' (tong chou) carried out through a vertical decision-making channel (Chung, 2015). That is, emergent mega-urban regional agglomerations as a whole, instead of the central-city focused region, become the focus and vehicle of the national state to create both endogenous and exogenous sources of economic growth.

For example, in 2013 President Xi Jinping announced the Chinese state’s plans to undertake an extensive programme of infrastructure development ostensibly designed to connect China's less-developed peripheral regions with neighbouring countries. The establishment of the Silk Road Economic Belt and 21st Century Maritime Silk Road or One Belt, One Road (OBOR) initiative can be viewed as a long-term geopolitical strategy on the part of the Chinese state to extend and strengthen China's external influence over those neighbouring states with which it has traded for several centuries. However, commentators, including Cai (2017), argue that the OBOR initiative in fact represents a last-ditch attempt by the National Development and Reform Commission (NRDC) to address mounting domestic political tensions associated with the 
This accepted manuscript is licensed under a Creative Commons Attribution-NonCommercial-NoDerivatives 4.0 International License.

widening of territorial-distributional disparities between less-developed provinces and cities in western China and the far more prosperous mega-urban regions of the East coast, including Shanghai and YRD.

The above periodization of city-regionalism in China is summarized in Table 2, which draws upon a heuristic framework proposed by Jonas and Moisio (2018, Table 1). Three stages in the geopolitical orchestration of city-regionalism are identified, each having distinctive national development context, political imaginaries, material practices, and city-regional knowledges. During the socialist period (1949-1978), sub-national regions were instruments of the party-state to consolidate political-economic control over the newly established national state space. The Soviet Union based theory of ‘regional production complexes’ (diyu shengchan zongheti) and ‘economic cooperation’ was applied to accelerate the process of industrial modernization, which was an integral part of state building. This gave way to a period of market reform and opening up (1979-2000), during which regions surrounding certain central cities became targets of policy experimentation, marketization and globalization with the potential trade-offs between economic liberalization and political stability. During this phase, the priority given to functional city-regions in national development was justified through the language of 'growth pole' and 'trickle down' economic theory.

+++Insert Table 2 'The geopolitics of city regionalism in China: a timeline' about here+++

The third phase (2001-present) is characterized by deepening state internationalization and growing domestic political, social and environmental problems related to uneven spatial 
This accepted manuscript is licensed under a Creative Commons Attribution-NonCommercial-NoDerivatives 4.0 International License.

distribution of economic growth within and between city-regions. During this phase, the national state re-coordinated city-regional development in order to counterbalance the growing polarization and over-concentration of growth in globally aspirational, large central cities such as Beijing and Shanghai. City-regional competitiveness and global city-region building, in turn, become powerful discourses for constructing collective regional identities and coalescing a variety of different levels of local and regional government within the broad rubric of the cityregion.

In summary, the trajectory of city-regionalism in China remains constrained by the legacy of the early socialist period when it served as a recipe to achieve national integration, conquer countervailing forces of state political and economic fragmentation and bolster the country’s geopolitical standing (Goodman \& Segal, 1994; Zhao \& Zhang, 1999). City-regional policy and planning has lately been justified as a means for various provinces and cities across China to perform specific roles identified by the state in the national political interest. Rather than exhibiting a globally uniform logic of city-regional resurgence at the expense the national state, in China it is possible to uncover a variety of different geopolitical motives and pressures, which over time have differently impact on how the Chinese state today orchestrates cityregionalism domestically and internationally.

\section{CHINESE EMERGENT CITY-REGIONALISM IN YANGTZE RIVER DELTA}

\section{REGION}

The remaining sections turn to a case study of YRD region - a coastal city-region surrounding Shanghai - in order to illustrate the countervailing geopolitical processes of cityregionalism in China. There has been a significant increase in literature documenting the rise of 
This accepted manuscript is licensed under a Creative Commons Attribution-NonCommercial-NoDerivatives 4.0 International License.

global city-regions in China, with YRD region often held up as an example of a powerful economic region with growing international significance extending well beyond the territorial borders of the Chinese state (Chen, 2007a; Zhao \& Zhang, 2007). The economic dynamism of YRD region is captured in dramatic images of Shanghai’s Pudong district with its gleaming skyscrapers and bustling river traffic, conveying a powerful message that YRD is one of China's pre-eminent global city-regions.

Nevertheless, if viewed exclusively as a global city-region, YRD becomes a pre-given or fixed territorial political construct when in fact its boundaries and constituent territories constantly change along with wider Chinese state formation processes (see Figure 1). Covered by an array of regional institutions and policies reflecting different phases of state intervention, a reinterpretation of YRD city-regionalism as a contingent geopolitical construct allows us to trace and chronicle its evolution in relation to wider processes of city-regional development in China. It is also an interesting city-region from a geopolitical standpoint because it has been the historic centre of internationalization through Shanghai’s unique connection to western countries. Moreover, as a centre of industrial unrest and the formation of the CCP in the 1920s and 30s, it occupies a symbolically significant political status in the historical development of the one-party communist state. In short, YRD is simultaneously a material reality and a geopolitical construct through which state internationalization and nationalization processes become more visible.

+++Insert Figure 1 'Changing boundaries and representations of YRD region' about here+++ 
This accepted manuscript is licensed under a Creative Commons Attribution-NonCommercial-NoDerivatives 4.0 International License.

Historically, YRD referred to a triangular alluvial plain at the lower end of the Yangtze River before it flows into the East China Sea. In ancient times, the area was known as the kingdom of $\mathrm{Wu}$ and its local dialects belong to the $\mathrm{Wu}$ linguistic system. Crisscrossed with rivers and lakes, the area to this day enjoys well-connected water transport and abundant yield of fish and rice. Throughout history, it has been one of the most commercialized and cosmopolitan parts of China with the Tai-Lake Basin, one of the biggest freshwater lake in China, its defining physical feature. As such, Shanghai did not become a city of great significance until the 1840s, when Shanghai Commercial Port opened under the jurisdiction of western imperial powers (France, Britain and the USA). Shanghai quickly developed into the largest financial centre in the Far East, attracting migrants from the surrounding region. Since then, viewed as an economic region YRD has always been more or less centred upon Shanghai and its hinterland, which in turn is connected to the rest of the world by port-related business activities.

After the creation of the People's Republic of China in 1949, the national positioning of YRD region underwent a series of material transformations and political re-imaginaries which can be (re)interpreted through the lens of the different geopolitical phases of city-regional development in China (see Table 2). In the first phase, the Cold War and centrally planned economic regulation meant the severing not only of Shanghai's ties to the world but also its connections with the rest of the country. The state transformed Shanghai from an international financial and trade centre to the largest socialist industrial city in China (Wu, 2003), grouping together contiguous provinces, such as Jiangsu and Zhejiang, with Shanghai not so much into a functional economic space but as a political-administrative unit called East China Economic Cooperation Region. That is, the political regional discourse of 'economic cooperation’ 
This accepted manuscript is licensed under a Creative Commons Attribution-NonCommercial-NoDerivatives 4.0 International License.

translated into state-mandated regional organization to facilitate state building by accelerating industrial modernization and ensuring national security.

In the second phase, the State Council designated the so-called Shanghai Economic Region (SER) based on the original YRD economic functional space. The region reclaimed its former national political and economic prominence when delegated as a national level economic region in the seventh national five-year plan (1986-1990). The political incentive underpinning this effort was to release and re-stimulate the historical regional economic vibrancy around Shanghai through relaxing the administrative control of productive forces (Li et al., 2000). Presented as a pioneering policy attempt to promote economic regionalization under the guidance of market, the creation of the SER was in fact a mandate of the central state party political apparatus. The leading office of the regional organization, the SER Planning Office, was immediately subordinate to the State Council and directly led by the National Planning Commission (the predecessor of NDRC) (The Yangtze River Delta Urban Economic Coordination Office, 2007).

The state abolished the SER in 1988 in line with its rhetorical commitment to voluntaristic market-oriented measures. Nonetheless, throughout the 1980s SER formulated many comprehensive and sectoral plans to direct regional economic development (Li et al., 2000). The agency’s work had thus founded a general development framework to forge a future Shanghai-centric city-region. First, it had re-established the central role of Shanghai in the national and regional economy. Secondly, regional transport infrastructure planning laid down the radial pattern of transport network with Shanghai as the central hub. Finally, regional development prioritized export-oriented economic growth in line with the regional model of PRD development in Hong Kong, which in turn paved the way for the opening-up of Pudong, 
This accepted manuscript is licensed under a Creative Commons Attribution-NonCommercial-NoDerivatives 4.0 International License.

Shanghai in 1990. The period from the 1980s to the 1990s can thus be seen as the state's early attempt to promote its marketization and internationalization agenda via the use of central city (growth pole)-led regional development strategy.

Since early 2000s, the Shanghai-centred city-region has become a strategic location for the development of global production clusters, which have been able to exploit urban-regional economies of agglomeration. In terms of global economic integration, Shanghai now ranks as China’s second global city after Hong Kong (Derudder et al., 2013). To some extent, the economic success of Shanghai and a global city imaginary constructed around Pudong have all but eclipsed YRD city-regionalism. Nonetheless, the political currency of the YRD city-region concept continues to manifest itself in documents prepared by NDRC and issued by the State Council, including the State Council's Guidance on Further Promoting Reform, Opening Up and Economic and Social Development in the YRD Region in 2008, the YRD Regional Plan (20092020), and the YRD Urban Agglomeration Development Plan (2016-2030) (the latter issued in 2010 and 2016 respectively). In these central documents, a national mission has been imposed top-down, which is to develop YRD into a global city-region economic powerhouse like its counterparts in Europe and along the Atlantic Coast of North America.

However, contained within these documents is another very different logic for promoting city-regionalism on the world stage. Instead of catering to a hyper-globalist vision of extensive city-region economic networks transcending the nation-state, the central documents reveal a desire to exercise stronger political control of domestic territory in the name of advancing regional competitiveness and upgrading industrial structures. Under the principle of city-regional coordination, not only have YRD regional boundaries been re-drawn by the central ministry, but also new spatial structures and functional divisions of the city-region been created. For instance, 
This accepted manuscript is licensed under a Creative Commons Attribution-NonCommercial-NoDerivatives 4.0 International License.

the Municipality of Shanghai is required to shrink its manufacturing capacity and accommodate more finance, advanced producer services and R\&D along the lines of other competitor global cities such as London and New York. In addition, the Municipality is instructed to control urban sprawl and cap population growth in order to alleviate environmental pressure. In turn, the formerly less developed and peripheral province of Anhui has been designated as the new development area within YRD to channel manufacturing away from Shanghai. As the former Vice Director of the local economy department of NDRC who oversaw the preparation of YRD Regional Plan has argued, only when the constituent localities of YRD region coordinate and cooperate within a functional division of labour will the region develop more efficiently and rapidly (Chen, 2007b, 28).

In sum, the trajectory of YRD regional evolution reflects the changing nature of national objectives and corresponding city-regional imaginaries. Industrialization and economic globalization have led to the regionalization of urban economies within YRD since the 1990s (Wu, 2017, 8). Throughout the process, Shanghai has played a pivotal role in leading regional development under the growth-pole strategy. Yet, at the same time, it has effectively reconcentrated much of the regional growth. Shanghai's growing ability to project a 'global city' imaginary on the world stage, along with the Municipality’s political status in national government, further indicate the potency of countervailing geopolitical processes. Indeed, the city-region around Shanghai is now expanding far beyond its original functional area. Instructed by the central documents, some formerly peripheral cities and provinces have been included in YRD, significantly expanding the region’s population from 78.4 million people in 2008 to 211.6 million in 2016, increasing its area by more than 300 per cent, and effectively upscaling the territory into a pre-eminent 'pan-region' or global city-region (Table 3). That is, the state 
This accepted manuscript is licensed under a Creative Commons Attribution-NonCommercial-NoDerivatives 4.0 International License.

characterizes the wider YRD region today in terms of closer economic linkages as well as a strong political culture of regional collaboration. Turning to this more recent period of state internationalization, the remaining sections unpack how these tensions and conflicts contribute to a more nuanced understanding of the contemporary geopolitical significance of city-regionalism both in YRD and China more generally.

+++insert Table 3 'Key economic indicators before and after YRD expansion' about here+++

\section{GEOPOLITICAL DYNAMICS OF CITY-REGIONALISM IN YRD REGION}

As documented in previous sections, the Chinese state launched its new economic policies of marketization and internationalization in the 1980s on the back of strategies that positioned the central city as a regional growth pole. This phase in the geopolitical orchestration of city-regionalism had profound distributional consequences for patterns and processes of cityregional development across YRD, concentrating much of the regional growth and distribution of wealth around Shanghai and municipalities in the eastern sector of the city-region. Measured by annual Gross Domestic Product (GDP), in 2016 regional income varied from less than 40 billion RMB (or yuan) in Anhui to well over two trillion RMB in Shanghai (Figure 2). While academic attention of late has focused on the striking problems of uneven development and diseconomies of agglomeration in YRD as well as across China (He et al., 2018), how emerging territorial-distributional tensions between well-developed and less-developed political jurisdictions feed into the wider geopolitics of city-regionalism is less well understood. This section considers how recent urbanization processes in YRD play into the internationalization of national state space in China before examining some countervailing geopolitical tendencies. 
This accepted manuscript is licensed under a Creative Commons Attribution-NonCommercial-NoDerivatives 4.0 International License.

+++Insert Figure 2 ‘GDP distribution within YRD in 2016 (Shanghai, Jiangsu, Zhejiang and Anhui)' about here+++

\section{The Internationalization of State Space}

Accelerated industrialization and economic globalization in YRD date from the CCP’s decision to open up the Pudong district of Shanghai in 1990. Shanghai was designated the 'head of the dragon' (a metaphor symbolizing its pivotal role not only in YRD but crucially also the nation at large). As an integral part of its internationalization strategy in the early 2000s, the national state crowned Shanghai as the centre of global economy, finance, trade and shipping (the so-called ‘four centres’ in government documents). Under the high-profile global positioning, a particular set of mega-projects - Pudong New District, Pudong International Airport, Yangshan super container ports, Hongqiao Transport Hub, China (Shanghai) Pilot Free Trade Zone, and so forth - were promoted. One prime example is the construction of Yangshan Deep Water Port beginning in 2002.

Given that Shanghai’s former role in global trade depended upon its commercial port, shipping today likewise enables Shanghai’s resurgence as a global metropolis (Wang \& Ducruet, 2012). Against the backdrop, the Municipality has been engaged in a major expansion of its port over four distinct construction phases and now covers more than 25 square kilometres (Li, 2009). With the final phase completed in 2017, the gigantic port has an annual throughput over 40 million TEU (Twenty-foot Equivalent Unit or equivalent to one-tenth of the global gross) and surpasses that of Hong Kong and Singapore as the largest container port in the world (Wang \& Ducruet, 2012). Thus far, the port has already redirected global shipping networks and given 
This accepted manuscript is licensed under a Creative Commons Attribution-NonCommercial-NoDerivatives 4.0 International License.

Shanghai a distinct advantage in the competition for shipping and as a trade centre in the Northeast Asia and beyond (Kim, 2014; Wan, Zhang, Wang, \& Chen, 2014). When featured in public plans and exhibitions, Shanghai’s efforts to promote logistics and port development ostensibly 'serve the nation'.

In addition to state-subsidized urban districts and mega-infrastructure projects, a set of world-class mega-events have also been located in Shanghai. The host of 2010 World Expo and the seat of the world's sixth Disneyland have successfully sold new images of Shanghai to would-be investors and to the world at large. With the explicit use of preferential policies, the state internationally orchestrates Shanghai as a candidate for global city status. According to Globalization and World City (GaWC) network rankings, Shanghai has already developed to be the gateway between its expanding regional hinterland and the global market (Taylor et al., 2014).

Lately, the Shanghai Municipal Government had unveiled its new plans, Shanghai Municipal Urban Planning (2016 - 2035). The latest master plan has projected an even stronger global-city imaginary. Rather than positioning itself as a global city candidate, Shanghai aspires to become a preeminent global city by 2035. According to the senior planner in charge of the plan,

It is no doubt that Shanghai has been developed into a global city already. So now we set our targets as 'striving for the excellent global city'. That is, Shanghai aims not only to be a global city, but to be a top global city (interview, senior planner, Shanghai, 2017, trans. from Chinese).

To create this capacity, the plan is dedicated to enhancing Shanghai's capability of innovation by further strengthening the function of global finance, forging the image of an 
This accepted manuscript is licensed under a Creative Commons Attribution-NonCommercial-NoDerivatives 4.0 International License.

international cultural metropolis, improving the environment and livability and attracting highlyskilled creative workers. A senior planner describes this change in emphasis as follows:

In the last round master plan released in 1999, Shanghai launched the construction of the mega-infrastructure projects such as the Yangshan supercontainer port. But no more manufacturing related facilities have been suggested in this round of planning and development because the command functions of Shanghai for manufacturing and global trade has firmly taken shape. What is pressing now is to enhance the quality of the city and build the municipality into an ecopolis thriving with innovation and culture (interview, senior planner, Shanghai, 2017, trans. from Chinese).

Yet the pivotal role of Shanghai within YRD rests not so much with its economic prominence on a global stage as its exceptional political status within the national political economy. As head one of the largest municipalities directly administered by the central government, the party secretary of Shanghai usually is the member of the Political Bureau of the CCP Central Committee. Shanghai holds significant economic and political power on the national stage as compared with other local and provincial jurisdictions within YRD region. In other words, Shanghai's ability to develop on its own instead of collaborating with the rest of YRD region is premised in part upon the political authority of the national state. However, Shanghai's gain comes at the expense of its neighbouring cities and the perceived benefits of regional collaboration, setting in motion countervailing geopolitical processes of cityregionalism.

\section{Countervailing Geopolitics of City-Regionalism}


This accepted manuscript is licensed under a Creative Commons Attribution-NonCommercial-NoDerivatives 4.0 International License.

Across the YRD, economic growth is mostly concentrated in the area immediately surrounding the Municipality of Shanghai and, as such, the ability of peripheral areas to prosper is profoundly constrained by the infrastructure network and (its lack of) connectivity. Indeed, even as Shanghai and its contiguous cities prosper socio-territorial disparities within the wider YRD region are appearing in the form of shrinking cities in peripheral districts and growing income disparities between eastern and western parts of YRD region (Long \& Wu, 2016). Growing regional disparities likewise factor into countervailing geopolitical discourses and practices associated with the Chinese state’s attempts to address chronic problems of uneven regional development throughout the national territory. In light of this, China's OBOR initiative functions not so much as a geopolitical device for managing the state's external relations with its neighbours as it instead serves as a conduit for addressing widening territorial-distributional disparities between city-regions in western China and expanding mega-urban regions, such as YRD, along the East coast.

Indeed, the historical concentration of mega-projects around Shanghai and subsequent efforts to redistribute economic activities across the wider YRD region have fostered countervailing geopolitical tensions and dynamics, which can be best illustrated by Shanghai’s relations with its surrounding jurisdictions. Close functional city-regional relations suffered badly at the turn of the twenty-first century when Shanghai began to build its 'four centres'. Following the goal to become a global shipping and trade centre, Shanghai Municipality initiated a plan to construct Pudong International Airport in addition to the existing one at Hongqiao. The Municipality further secured central government approval to build its own deep-water port at Yangshan. Both projects aroused great discontent among local jurisdictions in other parts of YRD. The Pudong International Airport located at the tip of Shanghai is much further away from 
This accepted manuscript is licensed under a Creative Commons Attribution-NonCommercial-NoDerivatives 4.0 International License.

the rest of the cities in the region. Amongst other factors, the new airport project potentially means the increase of time cost for the manufacturing especially information and communications technology industries concentrated in the cities immediately contiguous to Shanghai (Zhang \& Wu, 2006).

With regard to the deep-water port, there is no scope to build a large container port within Shanghai’s administrative territory due to hydrological constraints. Beilun Port at Ningbo (located in Zhejiang province), Taicang Port and Nantong Port (located in Jiangsu province) were constructed in the 1980s and 1990s to satisfy the needs of the future development of Shanghai (Zhang \& Wu, 2006). However, Shanghai was no longer favourable to the arrangement to achieve its status of 'four centres'. In order to have its own port, Shanghai spent nearly nine years lobbying the central government to approve the construction of the Yangshan deep-water container port (Zhang, 2015). The jurisdiction of the port lies half under the administration of Shanghai and half that of Zhejiang province. The project not only meant huge investment in terms of land reclamation as well as construction of a $30 \mathrm{~km}$ cross-sea bridge to connect the island with the land, but also political maneuvering to rent the island from Zhejiang in order to acquire the entire management power over the port.

These two projects came at a time when bottom-up regional cooperation began to pick up momentum and YRD city-regional integration turned into a policy catchphrase especially in the early 2000s. Yet the resultant regional competition around the port and airport competition was well documented (Comtois \& Dong, 2007). Public officials have articulated concerns that Shanghai - the 'big brother' - promotes inter-city competition rather than serves as a role model for city-regional cooperation (interview, academic, Shanghai, 2012, trans. from Chinese; informal discussions with officials, 2016). As Shanghai shifts its focus to innovation and 
This accepted manuscript is licensed under a Creative Commons Attribution-NonCommercial-NoDerivatives 4.0 International License.

developing cultural amenities, its relationship with surrounding territories and local jurisdictions seems far from improving. A local official from Kunshan, a county-level city that once advocated territorial integration with Shanghai, has complained about such ‘unequal’ relations:

Kunshan has developed a strong basis in terms of manufacturing and we really hope to upgrade our industrial structure, but now we are at a very difficult time....With Shanghai upgrading its industrial structure, it means little chance for Kunshan to develop its tertiary industry. While Shanghai [planned] to develop its e-commerce centre, Kunshan became the place for its warehouse. When Shanghai wanted to develop its financial centre, Kunshan became its call centre. When Shanghai catered to high-end human resources, Kunshan became the inhabitant for low-end workers. ... Now the spillover from Shanghai is negative [for Kunshan’s industrial upgrading] (interview, local government official, Kunshan, 2017, trans. from Chinese).

Neighbouring cities face many challenges in striving to counteract the centrifugal spatial forces fueling Shanghai's growth. A case-in-point involves a failed attempt by Kunshan to develop its own conference and exhibition industry. Kunshan recently built a large convention and exhibition centre with a total area of 1,650 thousand square meters in an attempt to attract spillover events from Shanghai’s exhibition activities. It is nevertheless vacant most of the time.

For the service industries, its centrifugal effect proves to be even stronger than manufacturing. In the last round of industrial development, we successfully attracted a lot manufacturing transferred globally. But not the case for producer services. Shanghai will not let them disperse outside of Shanghai (interview, local government official, Kunshan, 2017, trans. from Chinese). 
This accepted manuscript is licensed under a Creative Commons Attribution-NonCommercial-NoDerivatives 4.0 International License.

The over-concentration of growth in Shanghai has further prompted the state to direct growth towards the relatively underdeveloped territories of Zhejiang and Jiangsu, and the even more peripheral Anhui province. Based on the principle of a spatial structure consisting of 'one core area (Shanghai) and nine belts’ originally drawn up in the YRD regional plan, the latest YRD Urban Agglomeration Development Plan (2016-2030) proposes to construct five more metropolitan regions to counterbalance the economic power of Shanghai. In these respects, the formal and functional delimitation of YRD as a city-region continues to evolve and mutate as the Chinese state struggles to reconcile countervailing geopolitical forces operating within its territory.

\section{CONCLUSION: CITY-REGIONALISM AS COUNTERVAILING GEOPOLITICAL}

\section{PROCESSES}

This paper has offered a new interpretation of Chinese city-regionalism as a case of countervailing geopolitical processes at work both within and beyond national state borders. In a departure from post-Westphalian or hyper-globalist perspectives on the rise of global cityregions in a seemingly stateless world, the paper prioritizes a critical geopolitical perspective in order to open up new ways of examining the diverse territorial forms and motives associated with efforts to refashion state territory around city-regions. It suggests inter alia that a competitive mode of city-regionalism is not a necessary and inevitable territorial outcome of the rescaling of the state (Brenner, 2004; Wachsmuth, 2017). Nor is city-regionalism a process to be understood simply in terms of the rise of discrete territorial-political entities functioning separately from their host national territories (Scott, 2001). Instead, in its many different guises city-regionalism arises from various efforts on the part of the national state to address ever- 
This accepted manuscript is licensed under a Creative Commons Attribution-NonCommercial-NoDerivatives 4.0 International License.

changing geopolitical dynamics and territorial-distributional agendas operating within and beyond its borders. An especially novel contribution of the paper is its focus on how the state's efforts to internationalize itself often triggers countervailing geopolitical forces across its global city-regions, which in turn necessitate further adjustments to domestic city-regional structures and associated geopolitical alignments.

Focusing on the evolution of Chinese city-regionalism under Communist Party (CCP) rule since 1949, we have deployed a case study of YRD to reveal a range of countervailing geopolitical processes operating this ever-expanding Chinese city-region. In China, the territorial processes of city-regional development remain deeply imprinted in the CCP's national policy objectives, which today confront an evolving and unstable international context and widening domestic regional inequalities. On the one hand, new forms of city-regionalism emerging in and around YRD region reflect the Chinese state’s ongoing struggles to contain a domestic territorial 'politics of redistribution' (Cox, 2009). On the other hand, even as the state strives to transform YRD into a global city-region, Shanghai seemingly detaches itself functionally and discursively from the rest of the region. As such, Chinese city-regionalism needs to be re-examined as a contingent territorial-political construct that discloses powerful tensions operating within and beyond the national state and its one-party system

Besides offering a new interpretation of Chinese city-regionalism, this paper also raises three significant issues for further future research on the geopolitics of city-regionalism. Firstly, in lieu of the alleged demise of the nation-state, it is necessary to put the national question at the very centre of city-regional analysis. Rather than confirming the retreat of the nation-state around fuzzy and flexible city-regional territories which neatly align with the interests of global capital (Dierwechter, 2018; Scott, 2001; Taylor, 2011, 2013), the paper has revealed the tenacity of 
This accepted manuscript is licensed under a Creative Commons Attribution-NonCommercial-NoDerivatives 4.0 International License.

national state territorial interests in providing concrete form to city-regional imaginaries, processes and outcomes. Further research into different state formations could potentially confirm the continuing dominance of the national state in the evolving geopolitical landscape of city-regionalism.

Secondly, city-regional analysis opens up new opportunities to extend and refine Harvey’s (1985) tentative claims about the links between crises of devaluation, domestic urbanregional class alliances, and international geopolitical realignments. Whilst researchers have identified the many challenges of governance, planning and territorial administration posed by the rise of global city-regions (Scott, 2019), we know surprisingly little about the relationship between such domestic city-regional governance processes and new geopolitical alignments in the post-Cold War period. What is the role of supra-national organizations in enabling cityregional political actors to engage with new geopolitical alignments forged at the international scale? How do such alignments affect the flow of foreign direct investment into city-regions? How necessary is city-regionalism to the strategic coupling of the geo-economic interests of transnational firms and global production networks, on the one hand, and the geopolitical interests of the national state, on the other?

Thirdly and finally, there is scope to investigate how the balance of power between state and non-state political actors triggers countervailing geopolitical processes of city-regionalism (Harrison, 2010). In the Chinese context, the role of the central state is paramount yet there are signs that, as China's economy further internationalizes through new trade agreements and geopolitical alignments, non-state and quasi-state political actors (e.g. banks, property developers, port authorities) could deploy fixed investments and political resources in ways that alter the form and trajectory of Chinese city-regionalism. To what extent can non-state actors and 
This accepted manuscript is licensed under a Creative Commons Attribution-NonCommercial-NoDerivatives 4.0 International License.

political alliances shift the balance of forces of centralization and decentralization (collaboration versus competition) operating across city-regions? Finding answers to such questions could further light on the specificities of Chinese city-regionalism as well as on the countervailing geopolitical processes of city-regionalism operating in a variety of state contexts.

\section{Funding}

The first author disclosed receipt of the following financial support for the research, authorship, and publication of this article. Funding support from the National Natural Science Foundation of China (Grant Number: 41601157) is gratefully acknowledged. The second author disclosed receipt of the following financial support for the research, authorship, and publication of this article. Funding support from the Regional Studies Association, Fellowship Research Grant, is gratefully acknowledged.

Acknowledgements: [to be inserted]

\section{References}

Agnew, J.A. (1994) The territorial trap: The geographical assumptions of international relations theory. Review of International Political Economy, 1, 53-80.

Agnew, J.A. (1998) Geopolitics: Re-visioning world politics. London: Routledge.

Brenner, N. (2004). New state spaces: Urban governance and the rescaling of statehood. Oxford, NY: Oxford University Press. 
This accepted manuscript is licensed under a Creative Commons Attribution-NonCommercial-NoDerivatives 4.0 International License.

Bristow, G. (2013). State spatiality and the governance of economic development in the UK: The changing role of the region. Geopolitics, 18(2), 315-327.

doi:10.1080/14650045.2012.733784

Bunnell, T. (2002). Cities for nations? Examining the city-nation-state relation in information age Malaysia. International Journal of Urban and Regional Research, 26(2), 284-298. doi:10.1111/1468-2427.00380

Cai, P. (2017). Understanding China's belt and road initiative. Sydney, Australia: Lowy Institute for International Policy.

Calzada, I. (2018). Political regionalism: devolution, metropolitanization and the right to decide. In A. Paasi, J. Harrison and M. Jones (Eds.), Handbook on the geographies of regions and territories (pp. 231-242). Cheltenham, UK: Edward Elgar.

Cannon, T. (1990). Regions: spatial inequality and regional policy. In The geography of contemporary China: the impact of Deng Xiaoping's decade, ed. T. Cannon and A. Jenkins. London: Routledge.

Chan, K.W. (1992). Economic growth strategy and urbanization policies in China, 1949-1982. International Journal of Urban and Regional Research 16(2), 275-305.

Chen, X. (2007a). A tale of two regions in China: Rapid economic development and slow industrial upgrading in the Pearl River and the Yangtze River deltas. International Journal of Comparative Sociology, 48(2-3), 167-201. doi:10.1177/0020715207075399

Chen, X. (2007b). How can YRD enhance international competitiveness? Zhejiang. Today, 3, 28-29 (in Chinese).

Chung, H. (2015). Unequal regionalism: Regional planning in China and England. Planning Practice \& Research, 30(5), 570-586. doi:10.1080/02697459.2015.1076135 
This accepted manuscript is licensed under a Creative Commons Attribution-NonCommercial-NoDerivatives 4.0 International License.

Comtois, C., \& Dong, J. (2007). Port competition in the Yangtze river delta. Asia Pacific Viewpoint, 48(3), 299-311. doi:10.1111/j.1467-8373.2007.00349.x

Cox, K. R. (2009). 'Rescaling the state' in question. Cambridge Journal of Regions, Economy and Society, 2(1), 107-121. doi:10.1093/cjres/rsn029

Cox, K. R. (2013). Territory, scale, and why capitalism matters. Territory, Politics, Governance, 1(1), 46-61. doi:10.1080/21622671.2013.763734

Cox, K. R., \& Jonas, A. E. G. (1993). Urban development, collective consumption and the politics of metropolitan fragmentation. Political Geography, 12(1), 8-37. doi:10.1016/0962-6298(93)90022-y

Derudder, B., Taylor, P. J., Hoyler, M., Ni, P., Liu, X., Zhao, M. and Witlox, F. (2013). Measurement and interpretation of connectivity of Chinese cities in world city network, 2010. Chinese Geographical Science, 23(3), 261-273. doi:10.1007/s11769-013-0604-y

Dierwechter, Y. (2018). The smart state as utopian space for urban politics. In K. Ward, A. E. G. Jonas, B. Miller, \& D. Wilson (Eds.), International handbook on spaces of urban politics (pp. 47-58). London, UK: Routledge.

Fan, C. (2006). China's eleventh five-year plan (2006-2010): From "Getting Rich First" to "Common Prosperity". Eurasian Geography and Economics, 47(6), 708-723. doi:10.2747/1538-7216.47.6.708

Florida, R. (2008). Who's your city?: How the creative economy is making where you live the most important decision of your life. New York, NY: Basic Books.

Goodman, D. S. G., \& Segal, G. (1994). China deconstructs: Politics, trade and regionalism. London, UK: Routledge. 
This accepted manuscript is licensed under a Creative Commons Attribution-NonCommercial-NoDerivatives 4.0 International License.

Hall, P. (1999). The regional dimension. In B. Cullingworth (Ed.), British planning: 50 years of urban \& regional policy (pp. 76-90). Linton: Athlone.

Hall, P. (2009). Looking backward, looking forward: The city region of the mid-21st century. Regional Studies, 43(6), 803-817. doi:10.1080/00343400903039673

Harding, A. (2007). Taking city regions seriously? Response to debate on 'City-regions: New geographies of governance, democracy and social reproduction’? International Journal of Urban and Regional Research, 31(2), 443-458. doi:10.1111/j.1468-2427.2007.00736.x

Harris, S. (2014). China’s Foreign Policy (China Today). Cambridge: Polity.

Harrison, J. (2008). Stating the production of scales: Centrally orchestrated regionalism, regionally orchestrated centralism. International Journal of Urban and Regional Research, 32(4), 922-941. doi:10.1111/j.1468-2427.2008.00815.x

Harrison, J. (2010). Networks of connectivity, territorial fragmentation, uneven development: The new politics of city-regionalism. Political Geography, 29(1), 17-27. doi:10.1016/j.polgeo.2009.12.002

Harrison, J. (2012). Life after regions? The evolution of city-regionalism in England. Regional Studies, 46(9), 1243-1259. doi:10.1080/00343404.2010.521148

Harrison, J., \& Hoyler, M. (2015). Megaregions: Globalization's new urban form? Cheltenham, UK: Edward Elgar.

Harvey, D. (1985). The geopolitics of capitalism. In D. Gregory \& J. Urry (Eds.), Social relations and spatial structures (pp. 128-163). London, UK: MacMillan.

He, S., Bayrak, M. M., \& Lin, H. (2018). A comparative analysis of multi-scalar regional inequality in China. Geoforum, 78, 1-11. doi:10.1016/j.geoforum.2016.10.021 
This accepted manuscript is licensed under a Creative Commons Attribution-NonCommercial-NoDerivatives 4.0 International License.

He, S., \& Lin, G. C. S. (2015). Producing and consuming China’s new urban space: State, market and society. Urban Studies, 52(15), 2757-2773. doi:10.1177/0042098015604810

Huang, Y. (1996). Inflation and investment controls in China: The political economy of centrallocal relations during the reform era. Cambridge, UK: Cambridge University Press.

Huang, Y. (2006). Urban development in contemporary China. In G. Veeck, C. W. Pannell, C. J. Smith, \& Y. Huang (Eds.), China's geography: Globalization and the dynamics of political, economic, and social change (pp. 233-262). Boulder, CO: Rowman \& Littlefield Publishers.

Jonas, A. E. G. (2013). City-regionalism as a contingent 'Geopolitics of capitalism'. Geopolitics, 18(2), 284-298. doi:10.1080/14650045.2012.723290

Jonas, A. E. G., Goetz, A. R., \& Bhattacharjee, S. (2014). City-regionalism as a politics of collective provision: Regional transport infrastructure in Denver, USA. Urban Studies, 51(11), 2444-2465. doi:10.1177/0042098013493480

Jonas, A. E. G., \& Moisio, S. (2018). City regionalism as geopolitical processes. Progress in Human Geography, 42(3), 350-370. doi:10.1177/0309132516679897

Jones, M. and MacLeod, G. (2004). Regional spaces, spaces of regionalism: territory, insurgent politics and the English question. Transactions of the Institute of British Geographers, 29(4), 433-452. doi:10.1111/j.0020-2754.2004.00140.x

Kangas, A. (2013). Governmentalities of big Moscow: Particularising neoliberal statecraft. Geopolitics, 18(2), 299-314. doi:10.1080/14650045.2012.723288

Kantor, P., Lefèvre, C., Saito, A., Savitch, H. V., \& Thornley, A. (2012). Struggling giants: Cityregion governance in London, New York, Paris, and Tokyo. Minneapolis, US: University of Minnesota Press. 
This accepted manuscript is licensed under a Creative Commons Attribution-NonCommercial-NoDerivatives 4.0 International License.

Kim, J. I. (2014). Making cities global: The new city development of Songdo, Yujiapu and Lingang. Planning Perspectives, 29(3), 329-356. doi:10.1080/02665433.2013.824370

Kirkby, R.J.R. (1985). Urbanisation in China: town and country in a developing economy, 19492000 AD London: Croom Helm.

Li, C. (2009). Reclaiming the “Head of the Dragon”: Shanghai as China’s center for international finance and shipping. China Leadership Monitor, 28, 1-17.

Li, Y., \& Wu, F. (2012). The transformation of regional governance in China: The rescaling of statehood. Progress in Planning, 78(2), 55-99. doi:10.1016/j.progress.2012.03.001

Li, Y., \& Wu, F. (2018). Understanding city-regionalism in China: Regional cooperation in the Yangtze River Delta. Regional Studies, 52(3), 313-324. doi:10.1080/00343404.2017.1307953

Li, Z., Chen, Z., Yue, J., \& Wen, Y. (2000). Brief history of Shanghai economic zone. New Finance Editing Office (in Chinese).

Lim, K. F. (2016). On the shifting spatial logics of socioeconomic regulation in post-1949 China. Territory, Politics, Governance, 5(1), 65-91. doi:10.1080/21622671.2015.1099466

Long, Y., \& Wu, K. (2016). Shrinking cities in a rapidly urbanizing China. Environment and Planning A, 48(2), 220-222. doi:10.1177/0308518x15621631

Lord, A. (2009). Mind the gap. The theory and practice of state rescaling: Institutional morphology and the 'new’ city-regionalism. Space and Polity, 13(2), 77-92. doi:10.1080/13562570902999726

Luo, X., \& Shen, J. (2009). A study on inter-city cooperation in the Yangtze river delta region, China. Habitat International, 33(1), 52-62. doi:10.1016/j.habitatint.2008.04.002 
This accepted manuscript is licensed under a Creative Commons Attribution-NonCommercial-NoDerivatives 4.0 International License.

MacLeavy, J., \& Harrison, J. (2010). New state spatialities: Perspectives on state, space, and scalar geographies. Antipode, 42(5), 1037-1046. doi:10.1111/j.1467-8330.2010.00792.x

McGee, T. G. (1991). The emergence of ‘Desakota’ regions in Asia: Expanding a hypothesis. In N. Ginsburg, B. Koppel, \& T. G. McGee (Eds.), The extended metropolis: Settlement transition in Asia (pp. 3-26). Honolulu, Hawaii: University of Hawaii Press.

Mohan, G. and Tan-Mullins, M. (2018). The geopolitics of South-South infrastructure development: Chinese-financed energy projects in the global South. Urban Studies. Available in online first at: https://journals.sagepub.com/doi/10.1177/0042098018794351

Moisio, S., \& Jonas, A. E. G. (2018). City-regions and city-regionalism. In Paasi, A., J. Harrison \& M. Jones (Eds.), Handbook of regions and territories (pp. 285-297). Cheltenham, UK: Edward Elgar, 285-297.

National Statistical Bureau. (2016). China Statistical Yearbook 2015. Beijing: China Statistical Publishing House.

Neuman, M., \& Hull, A. (2011). The futures of the city region. Abingdon, UK: Routledge.

Ohmae, K. (1996). The end of the nation state: The rise of regional economies. New York, NY: Free Press.

Ó Thuathail, G. (1998). Postmodern geopolitics? The modern geopolitical imagination and beyond. In G. Ó Thuathail and S. Dalby (Eds.), Rethinking geopolitcs (pp.16-38). London: Routledge.

Park, B.-G. (2008). Uneven development, inter-scalar tensions, and the politics of decentralization in South Korea. International Journal of Urban and Regional Research, 32(1), 40-59. doi:10.1111/j.1468-2427.2008.00765.x 
This accepted manuscript is licensed under a Creative Commons Attribution-NonCommercial-NoDerivatives 4.0 International License.

Porter, M. (2001). Regions and the new economics of competition. In A. J. Scott. (Ed.), Global city-regions: Trends, theory, policy (pp. 139-157). Oxford, UK: Oxford University Press.

Rees, J., \& Lord, A. (2013). Making space: Putting politics back where it belongs in the construction of city regions in the North of England. Local Economy, 28(7-8), 679-695. doi:10.1177/0269094213501274

Robinson, J. (2006). Ordinary cities: Between modernity and development. New York: Routledge.

Roy, A. (2009). The 21st-century metropolis: New geographies of theory. Regional Studies, 43(6), 819-830. doi:10.1080/00343400701809665

Scott, A. J. (1998). Regions and the world economy: The coming shape of global production, competition, and political order. Oxford, NY: Oxford University Press.

Scott, A. J. (2001). Globalization and the rise of city-regions. European Planning Studies, 9(7), 813-826. doi:10.1080/09654310120079788

Scott, A. J. (2012). A world in emergence: Cities and regions in the 21st century. Cheltenham, UK: Edward Elgar.

Scott, A.J. (2019) City-regions reconsidered. Environment and Planning A: Economy and Space 51(3), 554-580. Doi: 10.1177/0308518X19831591

Scott, A. J., Agnew, J., Soja, E., \& Storper, M. (2001). Global city-regions. In A. J. Scott (Ed.), Global city-regions: Trends, theory, policy (pp. 11-32). Oxford, UK: Oxford University Press.

Storper, M. (2013). Keys to the city. Princeton, NJ: Princeton University Press.

Su, X. (2014). Multi-scalar regionalization, network connections and the development of Yunnan Province, China. Regional Studies 48(1), 91-104. 
This accepted manuscript is licensed under a Creative Commons Attribution-NonCommercial-NoDerivatives 4.0 International License.

Taylor, P., Derudder, B., Hoyler, M., Ni, P., \& Witlox, F. (2014). City-dyad analyses of China’s integration into the world city Network. Urban Studies, 51(5), 868-882.

doi:10.1177/0042098013494419

Taylor, P. J. (2011). World city networks: Measurement, social organization, global governance, and structural change. In M. Amen, N. Toly, P. McCarney, \& K. Segbers (Eds.), Cities and global governance (pp. 201-216). Farnham, UK: Ashgate.

Taylor, P. J. (2013). Extraordinary cities: Millennia of moral syndromes, world-systems and city/state relations. Cheltenham, UK: Edward Elgar.

The Yangtze River Delta Urban Economic Coordination Office. (2007). Through ten years: The history of the Yangtze river delta urban economic coordination in ten years' anniversary. Shanghai: Wenhui Press (in Chinese).

Wachsmuth, D. (2015). Megaregions and the urban question: The new strategic terrain for US urban competitiveness. In J. Harrison \& M. Hoyler (Eds.), Megaregions: Globalization’s new urban form? (pp. 51-74). Cheltenham: Edward Elgar.

Wachsmuth, D. (2017). Competitive multi-city regionalism: Growth politics beyond the growth machine. Regional Studies, 51(4), 643-653. doi:10.1080/00343404.2016.1223840

Wan, Z., Zhang, Y., Wang, X., \& Chen, J. (2014). Policy and politics behind Shanghai’s free Trade Zone program. Journal of Transport Geography, 34, 1-6. doi:10.1016/j.jtrangeo.2013.10.015

Wang, C., \& Ducruet, C. (2012). New port development and global city making: Emergence of the Shanghai-Yangshan multilayered gateway hub. Journal of Transport Geography, 25, 58-69. doi:10.1016/j.jtrangeo.2012.07.008 
This accepted manuscript is licensed under a Creative Commons Attribution-NonCommercial-NoDerivatives 4.0 International License.

Wang, S., \& Hu, A. (1994). A report on the capacity of the Chinese state. Hong Kong: Oxford University Press.

Wei, Y.H.D. (2010) Beyond New Regionalism, beyond Global Production Networks: Remaking the Sunan Model, China. Environment and Planning C Government and Policy, 28(1):7296. doi: $10.1068 / \mathrm{c} 0934 \mathrm{r}$

Wei, Y.H.D. (2017). Regional development in China: Transitional institutions, embedded globalization, and hybrid economies. Eurasian Geography and Economics, 48(1), 16-36. doi:10.2747/1538-7216.48.1.16

Woon, C.Y. (2018) China's contingencies: Critical geopolitics, Chinese exceptionalism and the uses of history. Geopolitics 23(1), 67-95. doi: 10.1080/14650045.2017.1302429

Wu, F. (2003). The (post-) socialist entrepreneurial city as a state project: Shanghai's reglobalisation in question. Urban Studies, 40(9), 1673-1698. doi:10.1080/0042098032000106555

Wu, F. (2010). How neoliberal is China's reform? The origins of change during transition. Eurasian Geography and Economics, 51(5), 619-631. doi:10.2747/1539-7216.51.5.619

Wu, F. (2016). China's emergent city-region governance: A new form of state spatial selectivity through state-orchestrated rescaling. International Journal of Urban and Regional Research, 40(6), 1134-1151. doi:10.1111/1468-2427.12437

Xu, J., \& Yeh, A. G. (2008). Planning the mega-city regions in China: Rationales and policies. Progress in Planning, 73(1), 17-22.

Xu, X., and Li, S.-M. (1990). China's open door policy and urbanization in the Pearl River Delta region. International Journal of Urban and Regional Research 14(1), 49-69. 
This accepted manuscript is licensed under a Creative Commons Attribution-NonCommercial-NoDerivatives 4.0 International License.

Yang, C., \& Li, S.-M. (2013). Transformation of cross-boundary governance in the Greater Pearl River Delta, China: Contested geopolitics and emerging conflicts. Habitat International, 40, 25-34. doi:10.1016/j.habitatint.2013.02.001

Yeh, A. G. O., \& Xu, J. (2011). China's Pan-Pearl river delta: Regional cooperation and development. Hong Kong: Hong Kong University Press.

Zhang, G. (2015). The tenth anniversary for the biggest container port in the world: The feasibility study and decision making that I had experienced. China Economic Weekly, 34-36 (in Chinese).

Zhang, J., \& Wu, F. (2006). China's changing economic governance: Administrative annexation and the reorganization of local governments in the Yangtze river delta. Regional Studies, 40(1), 3-21. doi:10.1080/00343400500449085

Zhao, S. X. B., \& Zhang, L. (2007). Foreign direct investment and the formation of global cityregions in China. Regional Studies, 41(7), 979-994. doi:10.1080/00343400701281634

Zhao, X. B., \& Zhang, L. (1999). Decentralization reforms and regionalism in China: A review. International Regional Science Review, 22(3), 251-281. doi:10.1177/016001799761012424 
This accepted manuscript is licensed under a Creative Commons Attribution-NonCommercial-NoDerivatives 4.0 International License.

Figure and table captions and sources (see published version for figures and tables)

Figure 1: Changing boundaries and representations of YRD region

Sources:

a. Redrawn with permission from Figure 7, Chen, Y. (2016). Understanding city expansion into larger city-regions: The case of the Yangtze River Delta. (Unpublished doctoral dissertation), Loughborough University, Loughborough, page 126.

b. Redrawn from Figure 2, Li, Z.; Z. Chen; J. Yue; and Y. Wen. (2000). Brief History of Shanghai Economic Zone. New Finance Editing Office, page 5.

c. Redrawn from Figure 2, The YRD Regional Plan (2009-2020), page 49: http://www.ndrc.gov.cn/zcfb/zcfbghwb/201006/t20100622_585472.html date of access $5^{\text {th }}$ November, 2018.

d. Redrawn from Figure 1, The YRD Urban Agglomeration Development Plan (2016-2030), page 2:http://www.ndrc.gov.cn/zcfb/zcfbghwb/201606/t20160603_806390.html Date of access $5^{\text {th }}$ November, 2018.

Figure 2. GDP distribution within YRD in 2016 (Shanghai, Jiangsu, Zhejiang and Anhui). Data sources: Jiangsu Statistical Bureau, 2017; Shanghai Statistical Bureau, 2017; Zhejiang Statistical Bureau, 2017; Anhui Statistical Bureau, 2017.

Table 1. Key territorial, economic and demographic indicators of YRD in 2015. Data sources: Compiled from China Statistical Yearbook (2016). 
This accepted manuscript is licensed under a Creative Commons Attribution-NonCommercial-NoDerivatives 4.0 International License.

Table 2. The geopolitics of city regionalism in China: a timeline.

Source: compiled by authors (after Table 1 in Jonas and Moisio, 2018).

Table 3. Key economic indicators before and after YRD expansion.

Data sources: Compiled from China Statistical Yearbook (2017) 